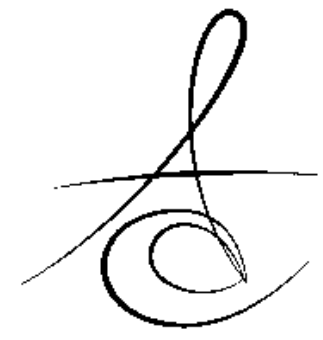

\section{INFLUENCE OF HOME AND OFFICE BLEACHING AGENTS ON COLOR AND TRANSLUCENCY OF COMPOSITE RESINS}

\section{KOMPOZİT REZİNLERİN RENK VE TRANSLÜSENTLİĞİNDE EV VE OFİS BEYAZLATMA AJANLARININ ETKİSİ}

Doç. Dr. Muhammet KARADAŞ*

\author{
Dr. Öğr. Üyesi Ömer SAĞSÖz**
}

Makale Kodu/Article code: 3756

Makale Gönderilme tarihi: 29.06 .2018

Kabul Tarihi: 17.10 .2018

\section{ABSTRACAT}

Aim: The purpose of this in-vitro study was to assess the effect of two bleaching agents on the color and translucency of aged composite resin materials (Filtek Z250, Estelite Flow Quick, and Tetric N-Ceram), as compared to re-polishing.

Material and Methods: Thirty composite discs from each material were made using circular molds, and were subjected to a thermocycling process for 5000 cycles, then immersed in the prepared staining solution. The aged samples were randomly divided into three treatment groups: re-polishing, $16 \%$ carbamide peroxide (Opalescence), or $35 \%$ hydrogen peroxide (Whiteness $\mathrm{HP}$ ). After aging and whitening treatments, the color reading was performed via a spectrophotometer. Color change $\left(\Delta \mathrm{E}_{00}\right)$ and translucency parameters were calculated. Data were evaluated by two-way ANOVA and Tukey's test $(p<0.05)$.

Results: Bleaching agents produced significantly higher color change in composite resins compared to repolishing $(p<0.05)$. Bleaching agents caused similar color change in each composite resin, but carbamide peroxide caused significantly higher color change in Filtek Z250 than hydrogen peroxide. Bleaching increased significantly the translucency of all aged composite resins. When bleaching agents were compared to re-polishing, only carbamide peroxide significantly increased the translucency of Filtek Z250. The re-polishing treatment did not significantly affect the translucency of Filtek Z250 and Estelite Flow Quick, whereas the translucency of Tetric N-Ceram significantly increased.

Conclusions: The applied treatments generated clinically perceptible whitening. The performance of bleaching agents was higher than that of re-polishing. The effect of bleaching agents on the translucency of composite resins depended on the material used and the treatment applied.

Keywords: Tooth bleaching, Color, Composite resins, Polishing

\section{öz}

Amaç: Bu çalışmanın amacl, yaşlandırımış kompozit rezinlerin renk ve translüsentliğinde iki farklı beyazlatma ajanının etkisini re-polisaj işlemi ile karşılaştırmalı olarak değerlendirmektir.

Gereç ve Yöntem: Silindirik kalıplar kullanılarak her bir kompozit materyalden 30 adet silindir örnek hazırlandı. Örnekler 5000 kez termal döngüye maruz bırakıldı, daha sonra renklendirici solüsyonda bekletildi. Yaşlandırılmış örnekler rastgele 3 tedavi grubuna ayrıldı; re-polisaj, \%16 karbamit peroksit (Opalescence), ve \%35 hydrojen peroksit (Whiteness HP). Renk ölçümü yaşlandırma ve beyazlatma tedavilerinden sonra spektrofotometre ile gerçekleştirildi. Renk değişimi $\left(\Delta \mathrm{E}_{00}\right)$ ve translüsentlik parametreleri hesaplandı. Veriler iki yönlü ANOVA ve Tukey's testi ile değerlendirildi $(p<0.05)$.

Bulgular: Beyazlatma ajanları re-polisaj işlemi ile karşılaştırıldığında önemli derecede yüksek renk değişikliği oluşturdu. Beyazlatma ajanları her bir kompozit rezinde benzer renk değişikliğine sebep oldu, yalnızca Filtek Z250 de karbamit peroksit hidrojen peroksitten yüksek renk değişikliği sağladı. Beyazlatma ajanları re-polisaj işlemi ile karşılaştırıldığında yalnızca karbamit peroksit Filtek Z250'nin translüsentliğini önemli derecede artırdı. Repolisaj işlemi Tetric N-Ceram'ın translüsentliğini artırmasına karşın, Filtek Z250 ve Estelite Flow Quick'in translüsentliğini etkilemedi.

Sonuç: Uygulanan tedaviler klinik olarak algılanabilir beyazlatma sağladı. Beyazlatma ajanlarının performansı re-polisaj işleminden yüksekti. Kompozit rezinlerin translüsentliğinde beyazlatma ajanlarının etkisi kullanılan materyal ve uygulanan tedaviye bağlıdır.

Anahtar Kelimeler: Diş beyazlatma, Renk, Kompozit rezinler, Parlatma

\footnotetext{
*Recep Tayyip Erdoğan Üniversitesi, Diş Hekimliği Fakültesi, Restoratif Diş Tedavisi AD, Rize

${ }^{* *}$ Atatürk Üniversitesi, Diş Hekimliği Fakültesi, Restoratif Diş Tedavisi AD, Erzurum
} 


\section{INTRODUCTION}

Composite resin materials have been commonly used in dentistry owing to their capacity to bond to tooth structures with adhesive technology and the use of micromechanical retention, and to provide esthetic properties. ${ }^{1}$ However, the discoloration of composite resins remains challenging in clinical dentistry. ${ }^{2}$ Staining of tooth-colored materials is the result of intrinsic and extrinsic factors. Food dyes, plaque accumulation, beverages, and surface degradation are extrinsic factors responsible for staining. The resin matrix composition, filler amount and size, photoinitiator type, and the biphasic nature of composite resins are intrinsic factors. ${ }^{3}$

Insufficient color is one of the major reasons for the replacement of composite restorations. ${ }^{4-6}$ The replacement of composite restorations requires considerable amounts of time and money. There are several methods of removing the stains from composite resin materials, such as brushing, polishing, or bleaching. ${ }^{7}$ Brushing or polishing eliminates the adsorbed stains on material surfaces. If the colorant pigments are incorporated into material, whitening techniques might be used.

Bleaching can be used as a treatment for teeth that are discolored due to extrinsic and intrinsic factors. Tooth bleaching generally involves the application of agents containing hydrogen peroxide (HP) or carbamide peroxide (CP) to the teeth in various formats. ${ }^{8}$ Hydrogen peroxide and free radicals released from bleaching agents can interact with colorant molecules and oxidize the pigment stains and macromolecules. ${ }^{8-10}$ The potential effect of bleaching products on composite resins is associated with the concentration and exposure period of the bleaching agent used, and the composition of the tested composite material. ${ }^{5,}{ }^{11}$ The limited studies that compare the effects of bleaching agents and repolishing on removing stains from composite resin materials have yielded controversial findings. ${ }^{7}, 12,13$ There are no studies evaluating the effect of home and office bleaching agents on the color and translucency changes of different composite materials.

The purpose of the present study was to evaluate the effect of two bleaching products on the color and translucency of three aged composite resin materials, as compared to re-polishing method.

\section{MATERIALS AND METHODS}

\section{Sample preparation and aging simulation}

Three different composite resins (Filtek Z250, Estelite Flow Quick, and Tetric N-Ceram) were used in this study. The technical profiles of the composite resin materials are presented in Table 1 . Thirty composite discs ( $2 \mathrm{~mm}$ thickness and $8 \mathrm{~mm}$ diameter) were prepared from each composite resin using circular molds. After loading the material into the mold, it was pressed between two thin glass covered with transparent sheets to remove excess material and eliminate voids. All composite resin materials were photo-polymerized with an LED curing device (VALO, Ultradent, USA) for $20 \mathrm{~s}$. The power output was checked by a dental radiometer (TREE, model TRP004). The upper surface of all samples was polished using sequential abrasive discs (Sof-Lex, 3M ESPE) for $15 \mathrm{~s}$. All samples were immersed in water for $24 \mathrm{~h}$ to complete polymerization.

Table 1. The properties of composite materials in this study.

\begin{tabular}{|l|c|l|c|}
\hline \multicolumn{1}{|c|}{ Material } & Lot no & \multicolumn{1}{|c|}{ Composition } & $\begin{array}{c}\text { Filler content } \\
\text { (vol/wt\%) }\end{array}$ \\
\hline $\begin{array}{l}\text { Tetric N-Ceram } \\
\text { (Ivoclar } \\
\text { Vivadent, USA) }\end{array}$ & T20645 & $\begin{array}{l}\text { Bis-GMA, UDMA, Bis- } \\
\text { EMA, barium glass, } \\
\text { prepolymer, ytterbium } \\
\text { trifluoride }\end{array}$ & $61 / 77$ \\
\hline $\begin{array}{l}\text { Estelite Flow } \\
\text { Quick } \\
\text { (Tokuyama } \\
\text { Corp, Japan) }\end{array}$ & E495 & $\begin{array}{l}\text { TEGDMA, Bis-GMA, } \\
\text { silica-titania filler, } \\
\text { silica-zirconium filler. }\end{array}$ & $49 / 68$ \\
\hline $\begin{array}{l}\text { Filtek Z250 } \\
\text { (3M ESPE, } \\
\text { USA) }\end{array}$ & N593226 & $\begin{array}{l}\text { Bis-EMA, TEG-DMA, } \\
\text { UDMA, Bis-GMA, } \\
\text { benzotriazole, silane- } \\
\text { treated ceramic. }\end{array}$ & $60 / 82$ \\
\hline
\end{tabular}

Composite resin samples were exposed to 5000 thermal cycles between $5^{\circ} \mathrm{C}$ and $55^{\circ} \mathrm{C}$ (dwell time, 25 $\mathrm{s})$. All samples were then stored in the mixture solution at $37^{\circ} \mathrm{C}$ for 6 days. The mixture solution was composed of four different beverages: coffee, black tea, grape juice, and orange juice. The coffee and tea solutions were prepared by adding $10 \mathrm{~g}$ of coffee or tea to $1000 \mathrm{ml}$ distilled water and boiling for $5 \mathrm{~min}$. The mixture solution was produced by adding equal parts of each solution (orange juice, grape juice, tea, and the coffee solution). The test mixture solution was renewed every day. After removal from the staining solution, samples were washed for $30 \mathrm{~s}$.

\section{Whitening treatments}

The aged samples from each material were randomly assigned to groups according to three

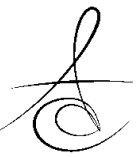


different whitening treatments ( $n=10)$ : re-polishing, $\mathrm{HP}$, or CP. Treatments were applied to samples embedded in wax plates as described below:

- Re-polishing: The upper surface of composite resin samples was polished intermittently with abrasive paper discs (coarse, medium, fine, superfine; SofLex, 3M ESPE) under dry conditions for $15 \mathrm{~s}$.

- HP: Bleaching agent (35\% WhitenessHP, Dentscare Ltda, Joinville-SC, Brazil) was applied to the upper surface of the composite resin specimens for $10 \mathrm{~min}$, then the specimens were washed with distilled water. The treatment was repeated three times on days 1 and 7 .

- CP: The upper composite resin surface was covered with bleaching gel (16\% Opalescence, Ultradent, South Jordan, USA) for 4 h. Samples were then washed thoroughly with distilled water. This application was repeated daily for 14 days. Between treatment sessions, samples were immersed in a darker container filled with deionized water at $37^{\circ} \mathrm{C}$. The bleaching treatments were performed at room temperature and according to the manufacturers' instructions.

\section{Color and Translucency measurements}

Color readings were taken at 2 time points (after staining and whitening) over black $(L=5.32, a$ $=1.98, b=-0.03)$ and white $(L=92.45, a=0.65, b$ $=3.01$ ) standard background via a spectrophotometer (Vita Easyhade, Advence Zanfabrik, Bad Sackingen, Germany). The color measurement of each sample was performed three times and the mean of the triplicates was used for the analysis. Before each measurement, the instrument was calibrated according to the manufacturers' instructions. Commission Internationale de l'Eclairage (CIE) $L^{*} a^{*} b^{*}$ values were recorded to calculate color change and translucency change. The $L^{*}$ value represents the light intensity (black (0) - white (100)). The $a^{*}$ value represents the degree of green/red color, whereas $b^{*}$ value represents the degree of blue/yellow color within sample.

Color change $\left(\Delta \mathrm{E}_{00}\right)$ was determined on the basis of the CIEDE2000 system using the following equation: ${ }^{14}$

$$
\Delta E_{00}^{*}=\sqrt{\left(\frac{\Delta L^{\prime}}{K_{L} S_{L}}\right)^{2}+\left(\frac{\Delta C^{\prime}}{K_{C} S_{C}}\right)^{2}+\left(\frac{\Delta H^{\prime}}{K_{H} S_{H}}\right)^{2}+R_{T}\left(\frac{\Delta C^{\prime}}{K_{c} S_{C}}\right)\left(\frac{\Delta H^{\prime}}{K_{H} S_{H}}\right)}
$$

where $\Delta L^{\prime}, \Delta C^{\prime}$, and $\Delta H^{\prime}$ are the differences in lightness, chroma, and hue, respectively, for a pair of samples; $S_{L} S_{C}$ and $S_{H}$ are the weighting functions for the lightness, chroma, and hue components, respectively; $R_{T}$ is a rotation function that accounts for the interaction between chroma and hue differences in the blue region; and $K_{L}, K_{C}$ and $K_{H}$ are the parametric factors for variations in experimental conditions. The parametric factors were set to 1.0 in this study. In the equation, $L^{*} a * b^{*}$ values taken against a white background were used. Values for $\Delta \mathrm{E}_{00}$ were calculated from color measurements at staining and after the whitening treatments.

The translucency parameter (TP) was calculated at each time point when color readings were taken, with the following equation:

$T P=\left[\left(L_{W}-L_{B}\right)^{2}+\left(a_{W}-a_{B}\right)^{2}+\left(b_{W}-b_{B}\right)^{2}\right]^{\frac{1}{2}}$

where the $W$ and $B$ subscript values represent color parameters taken on white and black backgrounds, respectively.

Statistical analysis was performed using parametric tests as a result of the normal distribution confirmed in the Shapiro-Wilks test. Two-way analysis of variance and Tukey's multiple comparisons test were applied at a significance level of $5 \%$.

\section{RESULTS}

Color change $\left(\Delta \mathrm{E}_{00}\right)$ means for each group are shown in Table 2. Both bleaching agents produced significantly higher color change in each composite material compared to re-polishing treatment ( $p<$ $0.05)$. Bleaching agents caused similar color change in composite resins, but only $\mathrm{CP}$ caused significantly higher color change in Filtek Z250 than HP ( $<<$ 0.0001).

Table 2. Mean value and standard deviation (SD) for color change $\left(\Delta \mathrm{E}_{00}\right)$

\begin{tabular}{|l|c|c|c|}
\hline Material & Re-polishing & HP & CP \\
\hline Filtek Z250 & $2.40(1.22)^{\mathrm{a}}$ & $4.07(1.55)^{\mathrm{b}}$ & $6.31(1.50)^{\mathrm{c}}$ \\
Estelite Flow Quick & $2.91(0.85)^{\mathrm{a}}$ & $3.64(1.06)^{\mathrm{b}}$ & $3.38(0.92)^{\mathrm{b}}$ \\
Tetric N-Ceram & $2.50(1.36)^{\mathrm{a}}$ & $3.82(0.83)^{\mathrm{b}}$ & $3.59(0.49)^{\mathrm{b}}$ \\
\hline \multicolumn{3}{|l|}{ The same letter in the horizontal line indicates no significant difference } \\
$(p<0.05)$.
\end{tabular}


Mean translucency values are shown in Table 3. The translucency of Filtek Z250 and Estelite Flow Quick was statistically not changed by re-polishing, whereas the translucency of Tetric $\mathrm{N}$-Ceram increased. Bleaching agents increased the translucency for all composite resins compared with staining, except for HP in Estelite Flow Quick. When bleaching agents were compared to re-polishing, only CP in Filtek Z250 increased significantly the translucency. There was no significant difference between bleaching agents regarding to the translucency of each composite resin.

Changes to $L^{*}, a^{*}$, and $b^{*}$ values (SD) against a white background are illustrated in Fig. 1 . In all composites, the $L^{*}$ and $b^{*}$ values decreased after the aging procedure, while the $a^{*}$ values increased, indicating a shift in the direction of black, blue, and red. The $L^{*}$ values increased for all composites after the different whitening treatments. Carbamide peroxide or HP produced a small difference in $L^{*}$ values compared to re-polishing. After treatments, $a^{*}$ values showed small changes for all composites. Carbamide peroxide or HP led to significantly decreased $b^{*}$ values in aged Filtek Z250 and Tetric NCeram.

Table 3. Mean value and standard deviation (SD) for translucency (TP)

\begin{tabular}{|l|c|c|c|c|}
\hline \multicolumn{1}{|c|}{ Material } & Staining & Re-polishing & HP & CP \\
\hline Filtek Z250 & $4.05(1.01)^{\mathrm{a}}$ & $4.79(0.73)^{\mathrm{ab}}$ & $5.70(1.36)^{\mathrm{bc}}$ & $6.74(1.63)^{\mathrm{c}}$ \\
Estelite Flow Quick & $6.51(1.07)^{\mathrm{a}}$ & $7.54(0.36)^{\mathrm{ab}}$ & $7.77(1.15)^{\mathrm{ab}}$ & $8.04(0.64)^{\mathrm{b}}$ \\
Tetric N-Ceram & $9.14(1.55)^{\mathrm{a}}$ & $10.81(0.94)^{\mathrm{b}}$ & $11.42(2.09)^{\mathrm{b}}$ & $11.48(3.37)^{\mathrm{b}}$ \\
\hline
\end{tabular}

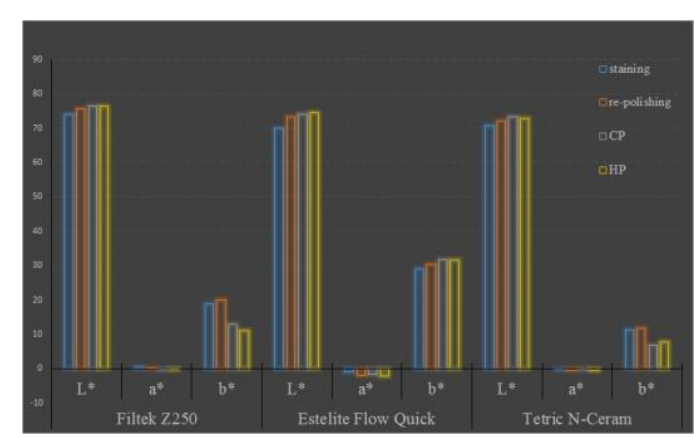

Figure. 1 The changes in color parameters for composite resins

\section{DISCUSSION}

Since composite resin materials endure thermal challenges and combinations of colors from common beverages and foods in the oral cavity, immersion in a single colorant solution of composite samples does not reflect the staining potential of human dietary intake. ${ }^{15}$ In the present study, to simulate the oral aging process, the composite samples were subjected to the thermocycling procedure and then immersed in a mixture prepared from beverages. ${ }^{15}$

Numerous studies have reported the efficacy of bleaching agents (at-home or in-office) ${ }^{5}, 16,17$ and even mouthwashes ${ }^{18}$ for removing stains from composite resin materials. However, these studies failed to prove the effectiveness of whitening agents compared to brushing or re-polishing. In this study, the color changes achieved with CP and HP were higher than that of re-polishing. This result supports the findings of a study by Turkun and Turkun ${ }^{7}$, who stated that in-office agents were more effective than re-polishing for restoring the color of stained composite materials. On the other hand, Garoushi et al. ${ }^{12}$ reported that the re-polishing procedure yielded a superior whitening effect compared to $40 \%$ hydrogen peroxide bleaching agent on stained composite materials. The contradictions between studies could be due to differences in the structure of the used material and in methodology.

Colorant pigments adsorbed on material surfaces may be removed by polishing procedures, while colorant pigments absorbed deep into the resin matrix cannot be easily removed..$^{13}$ According to the results of the present study, CP and HP can be predicted to be effective in removing colorants absorbed deep into composite materials when compared to re-polishing. The whitening level obtained on all aged samples with re-polishing was higher by at least three times than the clinically perceptible threshold level of $0.8\left(\Delta E_{00}\right)^{19}$, whereas the whitening level with bleaching agents was greater by at least four times than that. The reduction in staining of composite materials with bleaching treatments could be due to the degradation of surface pigments produced by high oxidizing of free per-hydroxyl radicals formed by the decomposition of HP. The mechanism of the color changes in composite resin materials caused by bleaching agents, without the 
presence of external staining products, is unknown. In the present study, it was observed that in addition to the removal of the colorant pigments, the yellowness of aged Filtek Z250 and Tetric N-Ceram decreased after bleaching treatments. Free per-hydroxyl radicals released from bleaching agents may induce oxidation of pigment macromolecules and amine compounds, which are responsible for the color stability of composites. ${ }^{20}$ These radicals might also accelerate the hydrolytic degradation of the composite materials ${ }^{21}$ and impact color changes.

A literature review determined that no significant difference regarding the efficacy of teethbleaching treatments has been found between athome and in-office bleaching, regardless of variations in the protocols of the bleaching techniques. ${ }^{22}$ In the present study, although HP (35\%) with a shorter contact time (total of $90 \mathrm{~min}$ ) had a higher concentration of hydrogen release than CP (16\%; $\sim 5.5 \% \mathrm{HP}$ ), CP had longer contact time (total of 56 h). No significant color and translucency differences on the composite materials were found between bleaching agents. Villalta et al. ${ }^{5}$ reported that the different concentrations of $\mathrm{CP}$ provided similar color changes on stained composite materials. In another study, it was reported that $\mathrm{CP}$ had better bleaching effects on aged composite resins than HP, which has been associated with longer contact time of CP (14 h). ${ }^{16}$ The discrepancies between the results of studies may be explained by differences in the studied composite materials and the bleaching agents used.

The translucency of tooth-colored restorations can be affected by pigmentation and changes on the body of the material. ${ }^{23}$ Despite a significant color change in aged materials, re-polishing may be insufficient to cause changes in translucency. The translucency change achieved by bleaching agents was varied and dependent on the tested composite resin type, which may be attributed to the difference in particle size and filler content. Only Filtek Z250 bleached with CP showed significantly higher translucency value when compared to the re-polishing. The light absorption is generated by the resin matrix, while scattering is due to the refractive index mismatch between the filler particles and resin matrix. ${ }^{24}$ Selective removal of larger filler particles from Filtek Z250 could have occurred after the longer period of application of CP. This led to the decrease in the difference in refractive index between the resin matrix and filler particles, allowing greater light penetration into the bulk of the material, therefore increasing translucency. ${ }^{24}$

It has been suggested that bleaching treatments can be a viable option for partially and totally removing the stains from discolored composite resins. ${ }^{16}$ However, bleaching gels lead to surface degradation, microcracks and reduction of gloss in composite resin, affecting its long-term clinical behavior. ${ }^{17,} 25$ Consequently, bleaching treatment can lead to disappointment in patients who plan a bleaching of natural teeth with restorations and composite veneering materials, and existing materials might require replacement after bleaching. Clinicians should be aware of changes on composite resin materials after bleaching and should inform patients before any kind of procedures.

Within the limitations of the present study, the bleaching agents generated clinically perceptible whitening $\left(\Delta E_{00}>0.8\right)$, and their performance was significantly higher when compared to re-polishing with regard to removing stains on composite materials. The effect of re-polishing on the translucency of aged composite materials depended on the structure of the composite resin. Bleaching agents significantly increased the translucency of aged composite resins.

Muhammed Karadaş: ORCID ID: 0000-0002-3357-6896 Ömer Sağsöz: ORCID ID: 0000-0002-6506-537X

\section{REFERENCES}

1. Burke FJ, McHugh S, Hall AC, Randall RC, Widstrom $\mathrm{E}$, Forss $\mathrm{H}$. Amalgam and composite use in UK general dental practice in 2001. Br Dent J 2003; 194: 613-8; discussion 09.

2. Diamantopoulou S, Papazoglou E, Margaritis V, Lynch CD, Kakaboura A. Change of optical properties of contemporary resin composites after one week and one month water ageing. J Dent 2013; 41 Suppl 5: e62-9.

3. Sarafianou A, Iosifidou S, Papadopoulos T, Eliades G. Color stability and degree of cure of direct composite restoratives after accelerated aging. Oper Dent 2007; 32: 406-11. 
4. Lu H, Roeder LB, Lei L, Powers JM. Effect of surface roughness on stain resistance of dental resin composites. J Esthet Restor Dent 2005; 17: 102-8.

5. Villalta $P$, Lu H, Okte $Z$, Garcia-Godoy $F$, Powers JM. Effects of staining and bleaching on color change of dental composite resins. J Prosthet Dent 2006; 95: 137-42.

6. Samra AP, Pereira SK, Delgado LC, Borges CP. Color stability evaluation of aesthetic restorative materials. Braz Oral Res 2008; 22: 205-10.

7. Turkun LS, Turkun M. Effect of bleaching and repolishing procedures on coffee and tea stain removal from three anterior composite veneering materials. J Esthet Restor Dent 2004; 16: 290-301; discussion -2 .

8. Joiner A. Whitening toothpastes: a review of the literature. J Dent 2010; 38 Suppl 2: e17-24.

9. Schemehorn B, Gonzalez-Cabezas C, Joiner A. A SEM evaluation of a $6 \%$ hydrogen peroxide tooth whitening gel on dental materials in vitro. $\mathrm{J}$ Dent 2004; 32: 35-9.

10. M Karadaş, N Seven. Vital dişlerde beyazlatma. Atatürk Üniv Diş Hek Fak Derg 2014: 126-35.

11. Xing W, Jiang T, Liang S, Sa Y, Wang Z, Chen X, et al. Effect of in-office bleaching agents on the color changes of stained ceromers and direct composite resins. Acta Odontol Scand 2014; 72: 1032-8.

12. Garoushi S, Lassila L, Hatem M, Shembesh M, Baady $L$, Salim $Z$, et al. Influence of staining solutions and whitening procedures on discoloration of hybrid composite resins. Acta Odontol Scand 2013; 71: 144-50.

13. Abd Elhamid M, Mosallam R. Effect of bleaching versus repolishing on colour and surface topography of stained resin composite. Aust Dent J 2010; 55: 390-8.

14. Luo MR, Cui G, Rigg B. The development of the CIE 2000 colour-difference formula: CIEDE2000. Color Research and Application 2001; 26: 340-50.

15. Ren YF, Feng L, Serban D, Malmstrom HS. Effects of common beverage colorants on color stability of dental composite resins: the utility of a thermocycling stain challenge model in vitro. J Dent 2012; 40 Suppl 1: e48-56.
16. Lago M, Mozzaquatro LR, Rodrigues C, Kaizer MR, Mallmann $A$, Jacques LB. Influence of Bleaching Agents on Color and Translucency of Aged Resin Composites. J Esthet Restor Dent 2016.

17. Canay S, Cehreli MC. The effect of current bleaching agents on the color of light-polymerized composites in vitro. J Prosthet Dent 2003; 89: 4748.

18. Harorli OT, Barutcigil C. Color recovery effect of commercial mouth rinses on a discolored composite. J Esthet Restor Dent 2014; 26: 256-63.

19. Paravina RD, Ghinea $R$, Herrera $L$, Bona $A D$, Igiel $C$, Linninger $M$, et al. Color difference thresholds in dentistry. J Esthet Restor Dent 2015; 27 Suppl 1: S1-9.

20. Turker SB, Biskin T. Effect of three bleaching agents on the surface properties of three different esthetic restorative materials. J Prosthet Dent 2003; 89: 466-73.

21. Soderholm KJ, Zigan M, Ragan M, Fischlschweiger W, Bergman M. Hydrolytic degradation of dental composites. J Dent Res 1984; 63: 1248-54.

22. de Geus JL, Wambier LM, Kossatz S, Loguercio AD, Reis A. At-home vs In-office Bleaching: A Systematic Review and Meta-analysis. Oper Dent 2016; 41: 341-56.

23. Ryan EA, Tam LE, McComb D. Comparative translucency of esthetic composite resin restorative materials. J Can Dent Assoc 2010; 76: a84.

24. Yu B, Lee YK. Differences in color, translucency and fluorescence between flowable and universal resin composites. J Dent 2008; 36: 840-6.

25. Anagnostou M, Chelioti G, Chioti S, Kakaboura A. Effect of tooth-bleaching methods on gloss and color of resin composites. J Dent 2010; 38 Suppl 2: e129-36

\author{
Yazışma Adresi \\ Doç. Dr. Muhammet KARADAŞ \\ Recep Tayyip Erdoğan Üniversitesi, \\ Diş Hekimliği Fakültesi, Restoratif Diş Tedavisi, \\ RİE \\ e-mail: muhammet.2005@hotmail.com
}

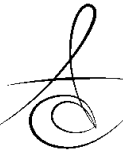

